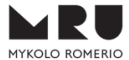

MYKOLO ROMERIO

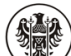

Uniwersytet Wrocławski
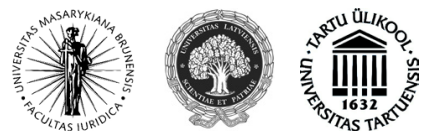

ISSN 1392-6195 (print) ISSN 2029-2058 (online) JURISPRUDENCIJA JURISPRUDENCE 2014, 21(3), p. 758-784.

\title{
THE RIGHT TO RESIST AND THE RIGHT OF REBELLION
}

\author{
Yulia Razmetaeva \\ Yaroslav Mudryi National Law University \\ Puskinskaya str. 77, 61024, Kharkiv, Ukraine \\ Tel.: +38057 7049272; +380501495005 \\ E-mail: akulina109@gmail.com
}

Received on 30 July, 2014; accepted on 19 September, 2014

doi:10.13165/JUR-14-21-3-06

\section{Introduction}

Revitalization of the socio-political processes and global changes in some states for a short period of time requires appeals to controversial issues, such as the resist to the public authorities, civil protests, disobedience and rebellion. The complexity of research of these issues is enhanced by the fact that they are located at the intersection of legal, moral and political themes and have special social exigencies.

Although in legal concepts the right to resist, the right to rebellion and the right to self-defense in its broadest sense is sometimes identified or used synonymously, the most accurate term seems just the right to resist. Their justifications traditionally derive from natural law, human rights, the principle of the lesser evil or of the social contract. The right to resist understanding tends to the interpretation through the law of peoples, in particular, the right to self-determination, and underscores the special nature of such right. Worth noting is the emergence of concepts, which declare intersecting with the essence of the right to resist ideas of "resistance on a

Jurisprudencija/Jurisprudence

(C) Mykolo Romerio universitetas, 2014

(C) Mykolas Romeris University, 2014
ISSN 1392-6195 (print), ISSN 2029-2058 (online) http://www.mruni.eu/lt/mokslo_darbai/jurisprudencija/ http://www.mruni.eu/en/mokslo_darbai/jurisprudencija/ 
small scale"1, "right to arms as a guarantee deterrent power"2, "self-defense against the state", "civil disobedience"4, "revolution of dignity" . Also, two-level research of the right to resist should be distinguished research of the right to resist - the first is a debate about the nature character and legislative consolidation of this right, partly focused on preventive-limiting its properties, whereas the second one is updated at the time of social upheaval and legal concerns, and it contains not only the evaluation of the events, but sometimes attempts to justify ex post risk of abuse and original post-legitimation of public authorities.

The history of the right to resist is traced from the sources of civilization and, in some sense, based on the ideas of the natural state. The first reference and recognition of such a right was found in the political and legal thought of ancient China. This doctrine continued and it was refelcted in the writings of Christian thinkers (primarily by Thomas Aquinas). Especially popular concept of resistance to tyranny was acquired by English and Scottish authors, such as John Locke, Thomas Hobbes, Samuel Rutherford, Algernon Sidney and others.

This had influenced the consolidation of different variations of the right to resist in documents, such as the Declaration of the Rights of Man and of the Citizen, 1789, the Declaration of Independence, 1776 (where not only the right was indicated but also the duty), the Universal Declaration of Human Rights of $1948^{6}$, a number of other declarations and charters. Now this right supports constitutions of many countries, as a percentage of more than one-fifth of their parts.

The ideas of resistance and rebellion, as soon as they prove to be out of date, lose their appeal and can be replaced by others, which proves their relevance in the truest sense. And the tradition of resistance that has arisen largely in the western world is not limited to its borders (for example, the Arab Spring). The fuel for a new debate about the resistance and rebellion can be given by the recent events in Ukraine (starting from November 2013 till the present day). So, talking about resistance and rebellion, the author of this paper will give examples related to Ukraine not only

1 Kaufmann, A. Small Scale Right to Resist. New England Law Review. 1985-1986, (21): 571-576.

2 Kopel, D. The Scottish and English Religious Roots of the American Right to Arms: Buchanan, Rutherford, Locke, Sidney, and the Duty to Overthrow Tyranny. Bridges. 2005, 12(3/4): 291312; Miller, D. Retail Rebellion and the Second Amendment. Indiana Law Journal. 2011, (86): 939-977.

3 Ferzan, K. Self-Defense and the State. Ohio State Journal of Criminal Law. 2008, (5): 449-478.

4 Lang, B. Civil Disobedience and Nonviolence: A Distinction with a Difference. Ethics. 1970, 80(2): 156-159; Moland, J. The Value-Oriented Civil Rights Movement and Passive Resistance: An Expression of Civility in the Pursuit of Social Justice. Sociological Inquiry. 2002, (72, 3): 442-455.

5 Guzar, L. Pravo na povstannja - to e zakon prirodi. 2014 [Husar, L. The Right to Rebel - That Is Natural Law]. [interactive]. [accessed on 2014-01-19]. <http://www.umoloda.kiev.ua/ number/2395/180/85201>. 
because they are well known, but also because they are very revealing. It must be said that Ukraine has long roots of the concept of resistance, the right of which was announced by the author of the first Ukrainian Constitution Philip Orlyk in 1712 as "the right to protest against oppression".

Despite numerous attempts at a theoretical justification of the right to resist, up to this day its systematic analysis has been insufficient. There are several commonly used areas of research focused on the concepts of political resistance and historical study of its manifestations or legal documents, as well as on issues of violent acts and peaceful civil disobedience, illegal occupation, humanitarian intervention and international aid. However, the legal nature, the content and form of the right to resist remain incompletely understood and cause many debates up to the doubt in the legal nature of this right. Therefore, the purpose of the article is to analyse the right to resist and the right to rebellion through the prisim of international humanitarian law, human rights law and the UN Charter. The conditions for the existence and implementation of these rights are shown in the present paper, as well.

The methods used in this research are dialectic, hermeneutical, comparative, historical, logical, functional systematic and other. Also, regulations, international and national legislation are analysed in the paper.

\section{International law and the right to resist}

Drawing attention to the international level consideration of the right to resist, it is necessary to say that in the relevant legal documents quite cautious approach can be traced, especially in the part which relates to the right to self-determination, as well as concerning intervention of the international community. Strictly speaking, to get the international community to recognize that in some state the right to resist now is being implemented or have been implemented can only overt, obvious violations of human rights by public authorities and numerous simultaneous actions of civil disobedience on the part of the people.

It is believed that modern international law does not contain a clear understanding of the right to resist. However, it can derive the following tendencies: (1) the international community and individual states cannot create artificial mechanisms for the implementation of the right to resist in other sovereign states; (2) if the population of a certain state implements the right to resist the authorities, the international community should refrain from technical and military aid to both sides, but this does not limit the possibility of providing to this state, including the rebels, humanitarian assistance; (3) the population, which realize the right to resist, is not recognized as a separate independent subject of international law, at the same time for this population, international law may provide some individual rights

7 Orlik, P. Vivid prav Ukraini. [Orlik, P. Conclusion Rights of Ukraine]. [interactive]. 1712 [accessed on 2014-08-25]. <http://cdiak.archives.gov.ua/v_do_300_Konstytutsii_Orlyka.php >. 
and guarantees; (4) the right to resist is linked to other global rights, such as the right to self-determination, the right to development and the right to peace ${ }^{8}$. One important element of the recognition of the right to resistance is the international recognition of the legitimacy of the changes that followed its implementation (for example, endorsement of a new government or acceptance and support for reforms). Recognition can be both legal and political, and it may have different forms. Sometimes to determine the nature of recognition is quite difficult, especially if the new government has not yet been formed. International recognition is more cautious if the resistance is not successful, even if the opposition groups have strong support of the people. Talmon writes about the features of recognizing the group as the legitimate representative of the people while the national government is still in place: "The rebellious opposition group may be recognized as: (i) a representative/ representatives of the aspirations of a people; (ii) a representative/representatives of a people; or (iii) the (sole) representative of a people. These three different statuses seem to be the major steps of what may be called the "career ladder of international recognition" of representatives of a people during a civil war. In all three cases, the opposition group is seen as an institution through which the recognizing State is engaging directly with the "people" within another State and by-passing that State's government. This must be distinguished from other, lesser forms of recognition, where the group represents only a fraction or section of a people". Talmon provides an example of Syria, where the nature of the conflict allows us to speak about the right to resistance and rebellion in their relationship with international humanitarian law. It should be noted that international humanitarian law is regarded as one of the sources of the right to resist, along with the right included in the statute of the United Nations (the issues of non-interference in the internal affairs of the State and responsibility to protect concept) and human rights law.

The international humanitarian law regulates the conduct of armed conflict and the protection of unarmed civilians, establishes a legal restriction and extent to which a force can be used. Resistance is certainly there in the territories of armed conflict, but it cannot be based only on international humanitarian law, which would lead to a too narrow understanding. First of all, in the situations of conflict, it is not about the resistance of legal public authority, which has lost legitimacy (an essential condition of the right to resist and rebellion, which will be presented in detail later), but the resistance to the occupation, illegal and illegitimate government. In addition, the occupation creates more specific rights and duties between the occupier and the people than that between the state and its citizens.

8 Babin, B. Pravo na soprotivlenie kak globalnoe pravo. [Babin, B. The Right of Resistance as a Global Right]. NB: Voprosy prava y politiki 2013, (5): 181-200 [interactive]. [accessed on 201405-02].<http://e-notabene.ru/lr/article_817.html>.

9 Talmon, S. Recognition of Opposition Groups as the Legitimate Representative of a People. Chinese Journal of International Law. 2013, (2): 228. 
Next, if the international humanitarian law is applicable, then we are dealing with armed resistance and problems of the civilian population, but it also narrows the scope of the understanding of the right to resist, which is excluded in peaceful, non-violent ways. And even if the right of rebellion is talked about, the rebellion may still be forcible, but not armed. Here, confrontation on the Maidan in Kiev and other Ukrainian cities, when protesters were unarmed and restrained police with their bare hands, with plywood a shield and any means at hand can be reminded as an example .

An example of another kind, which cannot be ignored, should also be presented - an example of Palestine. While the international community recognizes the Palestinians' right to resist and to fight for their independence, the situation of confrontation between Israel and Palestine is ambiguous. It had the wrong start and continued on both sides. Dugard and Reynolds provided examples of the numerous violations by Israel against the Palestinians and talked about "the legitimacy of the struggle of peoples under colonial and alien domination recognized"10. They also talked about the crimes against humanity: "In March 2012, the UN Committee on the Elimination of Racial Discrimination took the unprecedented step of censuring Israel under the rubric of apartheid and segregation as prohibited by Article 3 of the International Convention for the Elimination of All Forms of Racial Discrimination. Having reiterated previous concerns about the general segregation of Jewish and non-Jewish communities under Israeli jurisdiction, the Committee [...] urged Israel to prohibit and eradicate policies or practices of racial segregation and apartheid" ${ }^{11}$. Moreover, Israel has a vulnerable legal position on the Green Line ${ }^{12}$ and building to seal off the West Bank ${ }^{13}$. However, as rightly pointed by Zilbershats, "the very gravity of the crime requires that accusations of apartheid be made with the greatest caution. The accusation that Israel practises apartheid against the Palestinian population in the West Bank, East Jerusalem, and Gaza is unfounded and based on gross errors $[\ldots]$ the failure to differentiate between the norms governing occupied and sovereign territory, and the authors' complete failure to address Israel's policies in the context of an armed conflict characterized by the Palestinians' use of terror "14. The terror, in this form, as it is committed by Palestinians, goes beyond their right to resistance and rebellion, and is able to shake the valid claims of self-determination of the Palestinian people and the attitude towards them.

10 Dugard, J.; Reynolds, J. Apartheid, International Law, and the Occupied Palestinian Territory. The European Journal of International Law. 2013, 24(3): 878.

11 Ibid., p. 912.

12 Hilal, S. et al. The Lawless Line. London Review of International Law, 2013, 1(1): 201.

13 Legal Consequences of the Construction of a Wall in the Occupied Palestinian Territory (Request for Advisory Opinion) [2004] ICJ 28.

14 Zilbershats, Y. Apartheid, International Law, and the Occupied Palestinian Territory: A Reply to John Dugard and John Reynolds. The European Journal of International Law. 2013, 24(3): 916. 
In international law, there is the view that the right of resistance is not an independent right, and may be part of the right to self-determination. Sometimes it is also called the internal self-determination ${ }^{15}$.

Article 1 of the International Covenant on Civil and Political Rights of 16 December 1966 states that all people have the right to self-determination. By virtue of that right, they freely determine their political status and freely pursue their economic, social and cultural development ${ }^{16}$. The principle fixed in the Charter of the United Nations indicates that it is permissible to develop friendly relations among nations based on respect for the principle of equal rights and self-determination of peoples, and to take other appropriate measures to strengthen universal peace ${ }^{17}$. The principle of equal rights and self-determination of peoples should be considered in the context of the other principles of international law, especially such as the principle of non-interference and the principle of territorial integrity. In accordance with the Declaration on Principles of International Law Concerning Friendly Relations and Co-Operation among States in accordance with the Charter of the UN of 24 October 1970, nothing in the foregoing paragraphs shall be construed as authorizing or encouraging any action which would dismember or impair, totally or in part, the territorial integrity or political unity of sovereign and independent States conducting themselves in compliance with the principle of equal rights and self-determination of peoples as described above and thus possessed of a government representing the whole people belonging to the territory without distinction as to race, creed or colour. Every State shall refrain from any action aimed at the partial or total disruption of the national unity and territorial integrity of any other State or country ${ }^{18}$.

Since the principle of self-determination may conflict with other principles of international law, there are circumstances under which an extreme form of the right to self-determination (secession and the creation of the new state) can be realized. There are conditions of the postcolonial state ${ }^{19}$ or serious violations of the rights of a national minority ${ }^{20}$.

The separatist movements in a number of countries have used and continue to use an overly broad interpretation of the right to self-determination. However, in

16 International Covenant on Civil and Political Rights (of 16 December 1966, entered into force 23 March 1976) G.A. res. 2200A (XXI), U.N. Doc. A/6316 (1966), 999 UNTS. 171.

17 Charter of the United Nations, June 26, 1945, 59 Stat. 1031, T.S. 993, 3 Bevans 1153, entered into force Oct. 24, 1945, Article 1(2).

18 Declaration on Principles of International Law Concerning Friendly Relations and Cooperation among States in accordance with the Charter of the United Nations, G.A. res. 2625, Annex, 25 UN GAOR, Supp. (No. 28), U.N. Doc. A/5217 at 121 (1970).

19 Declaration on the Granting of Independence to Colonial Countries and Peoples, G.A. res. 1514 (XV), 15 U.N. GAOR Supp. (No. 16) at 66, U.N. Doc. A/4684 (1961).

Declaration on South Africa (adopted 12 Dec. 1979), A/RES/34/93O. 
2000 in the United Nations Millenium Declaration ${ }^{21}$ the UN mentioned the right of peoples to self-determination as a right of the people which remain under colonial domination and foreign occupation.

A striking example of the wrong justification of self-determination and juggling right to resist is the problem of the Crimea, which was annexed by the Russian Federation in March 2014, when the third force, the neighboring aggressor state, openly came on the Ukrainian revolution arena. Russian authorities appealed to the right of nations to self-determination. First, it cannot be regarded as subject to the law of nations to self-determination of the people of Crimea. "It is not a nation in ethnic or political sense, but is a regional community. In the context of talking about self-determination, Crimean Tatars, possibly with Krymchaks and Karaites, would have a special right to decide the fate of the Crimea, which is their historic homeland. However, the Russians decide, more precisely - the most aggressive of them, just as hostile to the Ukrainian and Crimean Tatar"22. "In European practice it right, in the form in which it treats by Russia does not exist. Moreover, it remains unclear definition of people of Crimea. The only national association in the Crimea, which has a claim to be the indigenous people - is the Crimean Tatar people"23. Second, the residents of the Crimea, some of whom say they have always dreamed of living in Russia, had a chance to implement it in 1991. "When the Soviet Union collapsed nearly 290 million of Soviet citizens fully exercised their right to self-determination both on a personal level and at the level of nations [...] there is no legal way to realize this right again. Any attempt in this direction is considered unacceptable by the international community, because force to take away someone else's land, someone else's property, destroys other people's property and physically and mentally cracking down on with other people - it is called robbery and banditry"24. In addition, the Crimean Tatars were not involved in the quasi referendum and did not recognize it. In March 31, 2014, the former chairman of the Mejlis and one of the leaders of the Crimean Tatar community, Mustafa Jemilev, made a statement that the Crimean Tatars boycotted the referendum. The referendum was attended not by $82 \%$ of the Crimean residents, as it was reported by the Russian authorities, but only by $32.4 \%$,

21 United Nations Millennium Declaration (adopted 8 September 2000) GA A/RES/55/2.

22 Kolodij, A. Pro Krimsku agreciju Putina i prabo nacij na samovoznachennja. [Kolody, A. The Crimean Aggression of Putin and the Right of Nations to Self-Determination]. 2014 [interactive]. [accessed on 2014-08-20]. <http://political-studies.com/?p=1071>.

23 Kozjubra, M. Vstupivshi do skladu Rosijskoi Federacii, Krim ne zmozhe u majbutnomu skoristatisja pravom na samoviznachennja. [Koziubra, M. Entering the Russian Federation, the Crimea Will not Be Able in the Future to Exercise the Right to Self-Determination]. 2014 [interactive]. [accessed on 2014-05-21]. <http://uacrisis.org/ua/mikola-kozyubra/>.

24 Siryj M. Krim. Pravo na samoviznachennja ne realizujetsja dvichi. [Siryi, M. Crimea. The Right to Self-Determination is not Implemented]. [accessed on 2014-03-16]. <http://www. radiosvoboda.org/content/article/25295825.html>. 
and it was held at gunpoint. First, Cossacks invaded the Crimea, seized government offices and parliament. Then Russian troops entered the Crimea ${ }^{25}$.

Thus, the right of people to self-determination and recognition of resistance, especially the right to rebellion, is most supported in case of people under colonial oppression, occupation. However, recognition of these rights is often careful. The UN gives a more negative evaluation in the case of the Apartheid. In this case, the right of resistance is actually recognized and specified. Notwithstanding the principle of non-interference in the internal affairs of States enshrined in the UN Charter, international law acknowledges that it cannot be used if serious human rights violations occur (genocide, war crimes, ethnic cleansing and crimes against humanity). This is especially evident in the UN initiative, namely - the responsibility to protect. This concept emerged in response to the fact that the state cannot cope with the responsibility to protect the population and this responsibility shifts to the international community and is used as a last resort as an intervention to protect the lives of people if other (non-military) measures have been ineffective ${ }^{26}$.

Therefore, although the acts of the UN condemn foreign aid to the rebels, they provide for the organization of such assistance within the framework of the UN, albeit with certain conditions. For example, in Resolution adopted by the General Assembly on 18 December 2012 (A/RES/67/121), acts of violence are condemned, including all acts of terror, provocation, incitement and destruction, and sanctioned humanitarian aid $^{27}$. In Resolution adopted by the General Assembly on 20 December 2012 (A/RES/67/183), the brutal suppression of the national liberation movements are condemned, but human rights violations by both sides of the civil war in Syria are admitted $^{28}$.

The interpretation of the right to resist at the international level is ambiguous, but it can be traced to a tendency to follow the principles of law, not hard rules. So, Kiivec writes about "reality adjustment modern international legal relations, which is characterized by a gradual departure from the classical sources of international law as an objective international legal category to justice - as subjective" 29 . And if

25 Dzhemiljev, M. Dzhemiljev v OON: milki krimski tatari majut pravo na samoviznachennja Krimu. [Jemilev, M. Jemilev in UN: Only Crimean Tatars Have the Right to Self-Determination Crimea]. 2014 [interactive]. [accessed on 2014-08-20]. <http://www.5.ua/ukrajina/politika/ item/377520-dzhemiliev-v-oon-tilky-krymski-tatary-maiut-pravo-na-samovyznachenniakrymu>.

26 Glanville, L. The Responsibility to Protect Beyond Borders. Human Rights Law Review. 2012 [interactive]. [accessed on 2014-08-21]. <http://hrlr.oxfordjournals.org/content/12/1/1.full >.

27 Israeli Practices Affecting the Human Rights of the Palestinian People in the Occupied Palestinian Territory, including East Jerusalem. GA Res. (adopted on 18 December 2012) A/ RES/67/121.

28 Situation of Human Rights in the Syrian Arab Republic. GA Res. (adopted on 20 December 2012) A/RES/67/183.

29 Kijvec, O. U poshukakh mizhnarodnogo praba: pereosmisljujuchi dzherela. [Kiivec, O. In Search for the International Law: Reinterpreting the Sources]. Kam'janec'-Podilskij: Oijum, 2011, p. 414. 
the implementation of the right to resistance is in line with these principles and is proportionate, then with high probability international recognition is guaranteed.

So, the right to resist cannot be deduced from the international law, although some ground can be found, including the international humanitarian law and the doctrine of responsibility to protect. In order to consider the following point of view, the concept of human rights will be referred to.

\section{The right to resist and human rights}

So, in what way the right to resist could be justified? Who and why has the opportunity to realize this right?

The Preamble of the Universal Declaration of Human Rights of 1948 is an explicit reference to the resistance in the form of rebellion: "it is essential, if man is not to be compelled to have recourse, as a last resort, to rebellion against tyranny and oppression, that human rights should be protected by the rule of law"30.

This right is reflected in many of the normative documents on human rights. It is often fixed at the constitutional level. "The justifying rationales behind constitutional right-to-resist provisions fall into three distinct groupings: (1) those that invoke a natural right trumping constitutional law; (2) those that create a citizen obligation to resist an overthrow of the current order; and (3) those that allow for the defense of individual rights against illegitimate actions or abuses undertaken by the state" ${ }^{\text {. }}$. Commitment to a specific justification depends on many factors, including the legal system type, government form, the people mentality, the oppression history, tyranny and repression, as well as the experience of resistance to them for a particular society. Often, a public authority, usually interested in reducing back the right to resist, requires that any acts remain within a narrow range or in any way are sanctioned by the state. In turn, the abuse of the right is possible by the members of the public, for example, the use of calls for changing the constitutional order or the initiation of protests as a means of obtaining public authorities.

Therefore, an important condition for the existence of the right to resistance is a legitimate aim. This could be called the internal condition, which is provided by those who implement this right. Other condition (which can be called external) and the base of implementation should recognize certain actions, acts or decisions by the public authorities - those that violate human rights are illegal and unfair.

At the same time, the purpose and result of the right to resistance may be changes in the public authorities, the termination of abuse of authority and violation of human rights by its agents, return to democratic legal regime or change in the

30 Universal Declaration of Human Rights, G.A. res. 217A (III), U.N. Doc A/810 at 71 (1948).

31 Ginsburg, T.; Lansberg-Rodriguez, D.; Versteeg, M. When to Overthrow Your Government: The Right to Resist in the World's Constitutions. UCLA Law Review. 2013, 60(5): 1221. 
constitutional system, aimed at creating a state of law, as well as in some cases when combined with the right to self-determination, - the achievement of independence.

If we consider that the right to resist belongs to human rights, it is important to understand if this is an individual right or a collective right. Who is a holder? Norms and constitutions of individual states often involve different statements regarding the rights' holder, for example, the holder of the right as "the people" or "the nation" is referred to in the Constitution of the Portuguese Republic on April 2, $1976^{32}$, in the Constitution of the Republic of Lithuania on October 25, 1992 $2^{33}$, in the Constitution of the Republic of Benin on December 2, 199034. The phrases "all citizens" or "citizens" may be used, for example, in the Constitution of the Slovak Republic on September 1, $1992^{35}$, in the Charter of Fundamental Rights and Basic Freedoms (an integral part of the Constitution of the Czech Republic on December 16, 1992) ${ }^{36}$. The phrase "every citizen" also can be used, for example, in the Constitution of the Republic of Estonia on June 28, 1992 ${ }^{37}$. It may also be the wordings "all Greeks", “all Germans", etc., for example, in the Constitution of Greece on June $11,1975^{38}$. It can also be an indefinite rights holder or a few holders, for example, according to Article 46 of the Political Constitution of Peru on December 29, 1993, "no one owes obedience to a usurper government or to anyone who assumes public office in violation of the Constitution and the law. The civil population has the right to insurrection in defense of the constitutional order" 39 .

This right can be explicitly stated in the text. For instance, in the Constitution of the Portuguese Republic on April 2, 1976, Article 21 is called "The right of resistance" ${ }^{\prime 0}$. The right of resistance may be inferred from the text of the Constitution, other norms, principles and rights. Such implicit recognition can be found in the Constitution of Ukraine on June 28, 1996. In Article 3, it is claimed that the state is

32 Constitution of the Portuguese Republic. Article 7. 1976 [interactive]. [accessed on 201408-21]. <http://app.parlamento.pt/site_antigo/ingles/cons_leg/Constitution_VII_revisao_ definitive.pdf $>$.

33 Constitution of the Republic of Lithuania. Article 3. Official Gazette. 1992, No. 33-1014.

34 Constitution of the Republic of Benin. Preamble. 1990 [interactive]. [accessed on 2014-08-21]. $<$ http://wwwl.umn.edu/humanrts/research/benin-constitution.html $>$.

35 Constitution of the Slovak Republic. Article 32. 1992 [interactive]. [accessed on 2014-08-19]. $<$ http://www.constitution.org/cons/slovakia.txt $>$.

36 Charter of Fundamental Rights and Freedoms. Article 23. 1992 [interactive]. [accessed on 2014-08-20]. <http://www.usoud.cz/en/charter-of-fundamental-rights-and-freedoms/>.

37 Constitution of the Republic of Estonia. Paragraph 54. 1992 [interactive]. [accessed on 201408-21]. <http://www.president.ee/en/republic-of-estonia/the-constitution/>.

38 Constitution of Greece. Article 120. 2008 [interactive]. [accessed on 2014-08-22]. <http:// www.hellenicparliament.gr/en/Vouli-ton-Ellinon/To-Politevma/Syntagma/>.

39 Political Constitution of Peru. Article 46. 1993 [interactive]. [accessed on 2014-08-22]. <http:// www.congreso.gob.pe/_ingles/CONSTITUTION_29_08_08.pdf>. 
responsible to the individual for their activities. Article 5 states that the only source of power is the people, who have the exclusive right to determine and change the constitutional order in Ukraine, and this right cannot be usurped by the state, its agencies or officials. Article 55 states that everyone has the right by any means not prohibited by law to protect their rights and freedoms from violations and illegal encroachments ${ }^{41}$.

Babin says that "the right to resist is the collective natural right. There are different defines the right to resist, defining its subject, as a collective ("the people"), individual ("every citizen") or by the number of indefinite ("all Germans", "citizens") and different terms of understanding conditions of realization such right (the presence of illegal orders, violent encroachments on the constitutional order or even any, even non-violent assault on democracy). The standards are placed in the text of the Constitution in various parts: where the basics of the social order and where human rights fixed" 42 . Pogrebnyak and Uvarova are of opinion that the right to resist is an individual right: "We can imagine three possible answers: a man, a citizen, or the people. Such a right should be treated as a human right [...]. In some cases, on the basis of the principle of solidarity to protect the rights from opression can join and other persons" ${ }^{3}$. Ginsburg, Lansberg-Rodriguez and Versteeg indicated that "the right to resist is sometimes an individual right and sometimes a collective one" ${ }^{\prime 4}$.

The author of this paper considers that the right to resist is the individual right. Moreover, it is a person, not necessarily a citizen, who owns this right, because the victims from the actions of the public authority may not only be the person having a stable political and legal relationship with a specific state.

Another question arises - is it possible to resist the implementation of the right individually? Is picket or protest carried out by one person, as it was during the Ukrainian events in November 2013 to March 2014, the implementation of the right to resist or other rights (for example, freedom of speech or the right to selfdefense)? The author of the present paper is inclined to the idea of the collective nature of the right to resist implementation, but warn against simply counting the number of persons engaged in it. In other words, it does not matter how many people commit acts, but it does matter how many people support them. The example of a demonstration against the Soviet invasion of Czechoslovakia in 1968 can be recalled,

41 Konstitucija Ukraini. [Constitution of Ukraine]. Vidomosti Verhovnoi Radi (VVR), 2014, No. 30-141.

42 Babin, B. Pravo na soprotivlenie kak globalnoe pravo. [Babin, B. The Right of Resistance as a Global Right]. NB: Voprosy prava i politiki. 2013, (5): 181-200 [interactive]. [accessed on 201405-02]. <http://e-notabene.ru/lr/article_817.html>.

43 Pogrebnjak, S., Uvarova, E. Soprotivlenie ugneteniju. Vosstanie. Revolicija (teoretiko-pravovoj analiz v svete doktriny prav cheloveka), [Pogrebnyak, S.; Uvarova, O. Resistance to Oppression. Rebellion. Revolution (Theoretical and Legal Analysis in the Light of the Human Rights Discourse)]. Pravo i gromadjanske suspilstvo. 2013, (2): 35-36. 
when only seven people were left on Red Square in Moscow. The example may be not too good in terms of consequences, but showing that the number of physically emerged to protest against actions of public authorities do not always match the number of people condemning the illegal policy of the state is relevant.

But how to determine the degree of support from the people's actions to implement the right to resist? By drawing an analogy with Miller, saying that "it is superstitious to blindly apply the unchecked majority principle to the practice of selfdetermination" 45 , the unchecked majority principle to practice of resistance should not be blindly applied. It appears that the majority of support can find embodiment not only in explicit actions (for example, mass rallies and demonstrations), but it can also be more difficult to establish forms, such as ensuring, and material assistance to the protesters, the dissemination of information about illegal acts of public authorities, and the search for like-minded and opponents conviction, public expression of support, and even suggest or tacit approval, sympathy. For example, very different groups from all regions of the Ukraine were on Maidan in Kiev. At some point, it reached 2 million people gathering in this place, not to mention the fact that local protests existed in almost every Ukrainian city.

The Ukrainian example also shows that the right of resistance is closely linked to the right to dignity. Protests on Maidan started as a spontaneous popular movement against unmotivated refusal of ex-president Viktor Yanukovych, who signed association with the EU. On November 21, 2013, it was a small gathering of people who have come after the post-call on Facebook from one of the wellknown journalists. But after the government did not react to people and especially when on November 30, 2013 the police brutally beat and dispersed the protest, the protest began to expand. Every cruel, unjust violation of human rights by the public authorities caused a new round of resistance and great support. Dignity does not allow a person to put up with disrespect and disregard by the government, repression and fear, ultimately posing a choice of what is more important: freedom and dignity or life? When a person chooses freedom and dignity, he is not just ready to resist, but also to rebel, and unfair public authority loses the fight.

Thus, the third condition of the right to resist is the support, as well as support and recognition, both internal and external. This raises the question as to the legitimacy of public authority and legitimacy of the opposing groups.

Talmon wrote that "practice in the cases of Libya and Syria shows that for an opposition group to be recognized as the legitimate representative of a people constituting a State, four criteria must be fulfilled. The incumbent government of the State must have lost legitimacy and the opposition group must be representative, broad, and enjoy a reasonable prospect of permanence" 46 . Returning to the example

45 Miller, R. Self-Determination in International Law and the Demise of Democracy? Columbia Journal of Transnational Law. 2003, (41): 648. 
of Ukraine, it should be reminded that the protest is supported not only by opposition groups, but also by a part of the Parliament. And after fleeing ex-president Viktor Yanukovych of the country on February 22, 2014, there were a legitimate, legally elected Parliament and the Cabinet of Ministers.

If the chronicle of events at the peak of the Ukrainian revolution is referred to, on February 21, 2014, the Parliament restored the constitution as amended in 2004 (Revision, which managed to cancel Viktor Yanukovych in 2010). President Viktor Yanukovych, in agreement with the parliamentary opposition and the pressure of the Ukrainian people and the international community, had to sign the law on the restoration of the Constitution of 2004. However, he did not do that and, what is even more, - disappeared in an unknown direction. Therefore, on February 22, 2014, at a meeting of the Parliament such actions were taken: the head of the Parliament was re-elected, a return to the Constitution of 2004 was confirmed, taking responsibility for everything that happens in the country, the adoption of resolutions that Yanukovych withdrew from the execution of constitutional powers and appointed a new special President election ${ }^{47}$.

In some cases, the lack of legitimacy of public power is obvious, especially when the situation grows out from resistance in a peaceful manner to full rebellion. Pogrebnyak and Uvarova wrote that "it comes an obvious gap in the line "legitimacylegality". For example, President, dismissed as a result of the rebellion, formally regarded as one who loss legitimacy, but to a certain point it was he is the legal head of state" ${ }^{\prime 4}$.

Talking about the modalities of implementing the right to resist, it should be noted that these forms can be active or passive, expressed directly or indirectly in actions. Active realization involves committing acts, such as participation in the protests, blocking the institutions, roads, bridges and other structures, up to actions "in arms". Passive realization consists of abstinence or denial of the subject from performing certain actions, for example, the rejection of the purchase of goods which are related to public authority representatives, absenteeism rallies in support of the government, ignoring the illegal demands of its representatives. Direct actions are civil initiatives protest actions, coordination and teamwork, public speaking. Mediated actions can be expressed in various forms of assistance to those who are directly involved in the protests against public authorities, information support, technical support.

47 Pro samousunenja Prezidenta Ukraini vid vikonannja konstitucijnikh povnovazhen ta priznachennja pozachergovikh viboriv Prezidenta Ukraini. [On Withdrawal of the President of Ukraine to Perform the Constitutional Powers and Calling Early Presidential Elections in Ukraine]. Vidimosti Verkhovnoi Radi (VVR), 2014, No. 11-158.

48 Pogrebnjak, S., Uvarova, E. Soprotivlenie ugneteniju. Vosstanie. Revolicija (teoretiko-pravovoj analiz v svete doktriny prav cheloveka), [Pogrebnyak, S.; Uvarova, O. Resistance to Oppression. Rebellion. Revolution (Theoretical and Legal Analysis in the Light of the Human Rights Discourse)] supra note 43, p. 39. 
Each person defines the limits of such support on their own. "Respect for diversity of tactics does not necessarily imply engaging in or even agreeing with the full range of tactics; rather, it holds that everyone has the right and the responsibility to identify their own thresholds of legitimate protest and to make their own political, strategical, and ethical choices, while also allowing others to do so free from public criticism or censure" 49 .

The right of resistance, thus, can be considered as an individual human right, which must have a legitimate aim, support and recognition and to be directed against the injustice of the public authority.

It can be considered as a consequence of the other human rights (based on the wording of the Universal Declaration of Human Rights). However, the author of this paper is of the opinion that the source is the concept of human rights, especially characteristics, such as universality and the natural character of rights. The right to resist exists, including as a way to protect other human rights.

It should also focus on the delimitation of the right to resist to other human rights - primarily for self-defense, freedom of expression, freedom of peaceful assembly.

The right to self-defense is another right generally associated with resistance. However, the right of resistance is not entirely the same as the right to self-defense. It is impossible not to note that self-defense can act as a way of resistance to a particular person or a group of persons, and in general it can be considered as a kind of reflection, an analog of the right to resist on a lower, individual level. Apart from the fact that self-defense is the individual level of implementation, there is a difference in the structure of these rights. If we look at the structure of the right, as Koller $^{50}$ and Alexy ${ }^{51}$ wrote, the right to self-defense can be addressed to any other owner of right, whereas the right to resist can be addressed to public authorities. Pogrebnyak and Uvarova wrote that "recipient of the right to resistance is a public authority (represented by the state authorities and local self-government authorities). It is important to emphasize that this is not about any power, but only about the power of undemocratic - tyrannical, oppressing" 52 .

It is noted that "the overwhelming consensus among the sources of international law, from ancient times to the present, among diverse legal systems, religions, and

49 Conway, J. Civil Resistance and the Diversity of Tactics in the Anti-Globalization Movement: Problems of Violence, Silence, and Solidarity in Activist Politics. Osgoode Hall Law Journal. 2003, 41(2/3): 511.

50 Koller, P. Die Struktur von Rechten. In Georg Meggle (Hg.). Analyomen 2. Proceedings des 2. Kongressses für Analytische Philosophie. Bd. 3. Berlin/New York, 1997, p. 251-262.

51 Alexy, R. Teorie der Grundrechte. 2nd edition. Frankfurt am Main, 1994, p. 171.

52 Pogrebnjak, S., Uvarova, E. Soprotivlenie ugneteniju. Vosstanie. Revolicija (teoretiko-pravovoj analiz v svete doktriny prav cheloveka), [Pogrebnyak, S.; Uvarova, O. Resistance to Oppression. Rebellion. Revolution (Theoretical and Legal Analysis in the Light of the Human Rights Discourse)] supra note 43, p. 35-36. 
nations: self-defense is a fundamental human right [...] It does seem apparent that it would be a violation of human rights law for a government to forbid self-defense, to forbid defensive training, or to forbid the possession of reasonably necessary defensive arms. No government has the legitimate authority to forbid a person from exercising her human right to defend herself against a violent attack, or to forbid her from taking the steps and acquiring the tools necessary to exercise that right" 53 . According to Miller, "right to self-defense extends to both private and public threats, including self-defense against agents of a tyrannical government. Moreover, the right is individual. Individuals - not just communities - have the right to protect themselves from public violence. Individuals - not just militias - have the right to defend themselves against tyranny" ${ }^{34}$. Ferzan writes about the moral justification of the right to self-defense and admissibility of various actions of self-defense, even if the state is unable to provide such protection. Communication between citizens, government and self-defense can be extremely complex, one or another concept may prevail, but to a greater or lesser extent, the self-defense will depend on the state. Furthermore, "the state's ability to protect us is essential to the state's overall legitimacy, to its legitimacy as to unprotected groups, and to its ability to legitimately punish individuals" ${ }^{\prime 5}$.

At the same time, as a consequence of the conditions of existence of the right to resist (as the right to self-defense), such controversial right is sometimes considered as the right to arms. Ambiguity is manifested primarily in the fact that, on the one hand, against this right its harmful effects on the other human rights are shown (homicide statistics and armed attacks in countries where it is legally enforceable), in support - something that the existence of this right keeps the government from abuses against its own people. Thus, according to Kopel, "one of the most important reasons that twenty-first century Americans are so attached to their guns is that they subscribe to the traditional American belief that citizens have a God-given right, and a correlative moral duty, to overthrow tyranny. Although the right of revolution can be found in diverse sources from many cultures, the source with the most influence on the founding of the United States was the seventeenth-century United Kingdom, where religious philosophers had articulated an explicitly Christian theory of the moral imperative for violent revolution against tyranny"56. Although in some states the right to arms is not questioned and acts as a really helpful restrictive-factor, experience of its recognizing and fixing cannot be mechanically transferred to other

53 Kopel, D.; Eisen, J.; Gallant, P. The Human Right of Self-Defense. BYU Journal of Public Law. 2008, (22) [interactive]. [accessed on 2014-03-26]. <http:://ssrn.com/abstract=1022097>.

54 Miller, D., supra note 45, p. 939.

55 Ferzan, K., supra note 3, p. 478.

56 Kopel, D. The Scottish and English Religious Roots of the American Right to Arms: Buchanan, Rutherford, Locke, Sidney, and the Duty to Overthrow Tyranny, supra note 2, p. 291, 292. 
models states. At least, one should take into account features of a particular society and to weigh the possible risks.

The right to resist stands alongside with the right to freedom of opinion and expression. This right includes freedom to hold opinions without interference and to seek, receive and impart information and ideas through any media and regardless of frontiers ${ }^{57}$. Also, the resistance is closely related to the right to freedom of peaceful assembly and association ${ }^{58}$. However, it is intersected, but not identical, with human rights.

\section{The right of rebellion as an extremal form of the right to resist}

Disputes about the terminology generate some misunderstandings in the understanding of the right to resist and the right to rebel. Here, we must also remember another concept - civil disobedience. These disputes are conducted mainly on violent or non-violent nature of the action described by the three mentioned terms. The situation is complicated by the emergence of new opportunities, expanding the range of human activities in the framework of resistance and civil disobedience.

For instance, Walter writes: "The concept of civil disobedience conjures images of peaceful protesters against oppressive governments and unjust laws. But with the expansion of economic globalization and perceived losses in states' abilities to regulate companies, activists have sought alternative ways of more directly addressing corporate power. Market campaigns, involving boycotts on the one hand and endorsements of companies committed to particular practices on the other, have taken on prominent status in the emerging response to domestic and transnational influences on states' regulatory capacity" 59 . In its turn, Lang points out that "[...] there is no such convergence that instances of nonviolent, political resistance may not be instances of civil disobedience, and (on the other hand) that acts which meet the criteria of civil disobedience need not be nonviolent [...] I assume that an act of civil disobedience must meet the following conditions: (1) the act will involve violation of a law; (2) the act will be performed intentionally, part of the intention being to

57 Universal Declaration of Human Rights, G.A. res. 217A (III), U.N. Doc A/810 at 71 (1948), Article 19; International Covenant on Civil and Political Rights (of 16 December 1966, entered into force 23 March 1976) G.A. res. 2200A (XXI), U.N. Doc. A/6316 (1966), 999 UNTS. 171, Article 19.

58 Universal Declaration of Human Rights, G.A. res. 217A (III), U.N. Doc A/810 at 71 (1948), Article 20; International Covenant on Civil and Political Rights (of 16 December 1966, entered into force 23 March 1976) G.A. res. 2200A (XXI), U.N. Doc. A/6316 (1966), 999 UNTS. 171, Article 21.

59 Walter, E. From Civil Disobedience to Obedient Consumerism - Influences of Market-Based Activism and Eco-Certification on Forest Governance. Osgoode Hall Law Journal. 2003, 41(2/3): 564 . 
effect change in the law violated or in a related law or policy; (3) the agent will make generally known his responsibility for the act and be willing to accept the punishment fixed by law for it" $"$.

Is it possible that watershed passes through a limited/unlimited resistance? "There is a reasonable, if sometimes indefinite, distinction to be drawn between limited resistance - which may count as civil disobedience - and resistance which resorts to any means, which would not" ${ }^{\prime \prime}$.

So, it can be argued that resistance is the most general concept (and right) and includes both non-violent and violent actions. These actions may, depending on the situation, be qualified as a peaceful protest or civil disobedience, and in exceptional cases - to grow up into a rebellion.

Some authors point to the exclusive nature of the right to resist, its implementation only when actually there is no alternative. They have written that "the right to resist is commonly perceived as a right of last resort, triggered only in the most extraordinary circumstances of illegitimate government action. It moreover argues that the right to resist is distinct from other rights because of its second-order character. That is, rather than provide a particular substantive limit on state authority, the right to resist serves as an enforcement mechanism to protect other constitutional rights" ${ }^{\prime 2}$. The author of the present paper agrees with the special role of this right as means of coercion of public authorities to ensure respect and observance, realization and protection of human rights. However, in the above sense, it is more the right of rebellion. The last one is really an extreme form of the right to resist, which expresses namely the violent course of action and which affects more stringent requirements on the conditions of its existence and implementation.

As rightly argued, the right to resist is justified when "all legal and peaceful remedies have been exhausted" 63 . But, in our understanding, it is applicable to the right to rebel. Besides the exhaustion of non-violent means of resistance, the basis of realization of the right to rebel can be clear and undoubted inefficiency of these means.

The right to rebel also requires certain actions by the public authorities. According to the Honoré, the right to rebel can be realized "in the event of the violation on a large scale of primary rights like the right to freedom from arbitrary arrest. The sustained denial of those rights may amount to such oppression or exploitation as justifies rebellion" ${ }^{64}$. So, other conditions (and bases) of the right of rebellion are phenomena, such as the following: (1) massive human rights violations by public authorities (quantitative criterion); (2) systematic human rights violations by public

60 Lang, B., supra note 4, p. 156.

61 Ibid., p. 159.

62 Ginsburg, T.; Lansberg-Rodriguez, D.; Versteeg, M., supra note 31, p. 1190.

63 Kaufmann, A., supra note 1, p. 574.

64 Honoré, T. The Right to Rebel. Oxford Journal of Legal Studies. 1988, 8(1): 38. 
authorities (accumulating criterion), or (3) extraordinary human rights violations by public authorities (criterion by serious, explicit and violent nature of the violation).

Namely, massive human rights violations may entail the simultaneous exercise of the right to rebel and the right to self-determination. As it has been noted, "massive violation of human rights causes acute social upheaval, promotes inter-ethnic and inter-ethnic conflicts. Conversely, the promotion and protection of human rights, their distribution among the ethnic communities helps establish impartial relations between indigenous people and ethnic groups and immigrant communities"65.

The activities initiated as a realization of the right to resist could escalate into a rebellion, especially in cases where the level of abuse by the public authorities only increases in response to protests acts and events. When this level is unbearable and there is no other alternative way, the right to rebel comes into force.

One of the most acute problems of the study of the right of rebellion is a controversial and ambiguous nature of some of the ways to implement it. Violent and especially armed resistance, committing illegal actions, going beyond the legal field - all of this may accompany the implementation of this right. Which methods are acceptable and proportionate? How to solve the problem of legal liability of the persons directly or indirectly involved in the rebellion? Is it possible to develop and fix the mechanism of realization of this right, not only confirm the fact of its existence by legislation?

According to Babin, such right "does not and cannot be the written law mechanism for implementing. But the mechanisms of external legal assessment of social conflict as a possible realization of the right to resist and the possible legal consequences of such conflicts are promising topic for further research in today's politically unstable world"66.

His Beatitude Cardinal Lubomyr Husar (the former head of the Ukrainian Greek Catholic Church) underlines that "there are situations where armed resistance is permitted. When the government uses excessive force, people have the right to defend themselves armed. Each of the us has the right to defend themselves [...] It is not necessary to prescribe that in the constitutions - that is the law of nature. I have the right to defend themselves and your loved ones. As everyone. And I have the right to answer such means that I am attacked. Arms can be taken when the weapon is used against you"67.

Many authors rightly point to the realization of the rebellion as limited: "The legitimacy of a rebellion or revolution does not legitimize the use of certain tactics or

65 Rimarenko, S. Prava nacii ta prava ljudini: mizh Sciloju i Kharibdoju. Kiiv: Svitlograd, 2005, p. 11.

66 Babin, B. Pravo na soprotivlenie kak globalnoe pravo. [Babin, B. The Right of Resistance as a Global Right]. NB: Voprosy prava y politiki. 2013, (5): 181-200 [interactive]. [accessed on 2014-05-02]. <http://e-notabene.ru/lr/article_817.html>.

67 Guzar, L. Pravo na povstannja - to e zakon prirodi. [Husar, L. The Right to Rebel - That Is Natural Law]. 2014 [interactive]. [accessed on 2014-01-19]. <http://www.umoloda.kiev.ua/ number/2395/180/85201>. 
conduct that are absolutely proscribed under international law"68. "In contrast to the similar provisions of the laws and customs of war, civilian casualties are absolutely unacceptable. Rule absence of civilian casualties is also a feature that distinguishes the right of revolution of self-defense, which sometimes leads to the innocent victims. Revolutionary force can be directed only against persons who are actively involved in the actions of the repressive regime" 69 . "Two salient features characterize the Syrian civil war. One is the endemic disregard for the law of armed conflict on the part of government as well as anti-government forces [...] A second feature is the degree of third-State support on both sides"70.

Thus, the right to rebel can be justified, but going beyond its implementation cannot.

That is why the rebellious Ukraine and Syria or Palestine cannot be compared. And this is one of the arguments why theevents in Donetsk and Lugansk regions of Ukraine, which are continuing today, cannot be called rebellious. Among other arguments is that pro-Russian protesters have an illegitimate purpose, that they have other effective methods of protest (peaceful means have not been exhausted), the fact that public authority is ready to hold a dialogue with them. It is also not a civil war, because there is the presence of military and financial aid and military intervention in the Russian Federation.

However, to put the rebellion into the framework is rather difficult. Difficulty appears in the external evaluation mechanism in its retrospective nature (as well as the degree of involvement in the events). Taking into account legal consequences, we must apply primarily to the principle of justice and the priority "the spirit" of law over the "letter". Court could give an assessment in this case, subject to compliance an independent, objective and impartial, and reasonable consideration.

The idea of the methods of resistance with the help of the court deserves special attention. In particular, in such an understanding, the role of the court may be reduced to the function of the limits definition of what is permitted in the resistance and issues about the responsibility of individuals. The problem is the fact that the court may be on the side of public authorities to support lawlessness and injustice, contrary to the principles of law and the idea of justice. Wall, speaking of judicial processes, argues that "the power of civil disobedience is that it causes the government to look at its own actions and fully accept responsibility for them. It raises the bar,

68 Paust, J. International Law, Dignity, Democracy, and the Arab Spring. Cornell International Law Journal. 2013, (1): 14.

69 Pogrebnjak, S.; Uvarova E. Soprotivlenie ugneteniju. Vosstanie. Revolicija (teoretiko-pravovoj analiz v svete doktriny prav cheloveka), [Pogrebnyak, S.; Uvarova, O. Resistance to Oppression. Rebellion. Revolution (Theoretical and Legal Analysis in the Light of the Human Rights Discourse)]. Pravo i gromadjans'ke suspil'stvo, supra note 43, p. 53.

70 Ruys, T. Of Arms, Funding and "Nonlethal Assistance" - Issues Surrounding Third-State Intervention in the Syrian Civil War. Chinese Journal of International Law. 2014, 13(1): 14. 
making it uncomfortable for a government to continue unpopular policies"71. Rubin writes about the need for judicial control of public authorities and that the court may confirm the right to resist or revolt ${ }^{72}$. But the author of the present papers does not agree with Pettit, who writes about the need for a way of opposing laws within the system $^{73}$. As he writes, "the legitimacy requires citizens to oppose the laws they take to be unjust, if indeed they choose to oppose them, only within the system; it requires them to explore only the avenues that the system leaves open"74. Such resistance can be really effective, but only to the extent that the court is effective in one or another society. In the case of Ukraine, it is convinced that the appeals to court are not enough to turn the tide in favor of the people, especially if the court is an instrument of unfair public authorities. When resistance develops into a rebellion, then duration of judicial review in a rapidly changing environment, as well as a total distrust of justice are added to the shortcomings of such methods. But where the court does not look like a weather vane under the breath of the authorities, its decisions can cause drastic changes in the society.

At the end, its cost gives a quote, which is now very relevant for the Ukrainian society and the state: "Presumably, if the right to resist is properly exercised, the state has a duty not to repress those engaged in it. Such repression might conceivably lead to criminal liability, either on the international plane or in local courts after a political transition, on the part of state agents that engage in such repression"75. It should be noted that these words fall exactly into the realities of our existence, while the achievement of results in the form of prosecution of some representatives of public authorities can be a long way. At the same time, people who have realized the right to resist, even if it is carried out in an extreme form of rebellion, shall not be held liable if they have not violated limits of the implementation of this right.

In general, the right to resist can be a good tool to limit possible actions, decisions and acts of the public authority and a reminder of the value of human rights and that the source of this power is the people. However, the fundamental rights and freedoms must be protected.

\section{Conclusions}

Thus, the right to resist serves as an individual human right, the owner of which is the person and can be collectively realized as a subject to the availability

71 Wall, I. The Defence of Conscience: A Limited Right to Resist. Hibernian Law Journal. 2004, 4(1): 288.

72 Rubin, E. Judicial Review and the Right to Resist. The Georgetown Law Journal. 2008, (97): $117-118$.

73 Pettit, P. Legitimacy and Justice in Republican Perspective. Current Legal Problems. 2012, (65): 62.

74 Ibid., p. 65.

75 Ginsburg, T.; Lansberg-Rodriguez, D.; Versteeg, M., supra note 31, p. 1195. 
of the legitimate aim (the internal condition) in response to the illegal, unfair and violate human rights actions, decisions or acts of public authorities (the external condition of implementation). The third condition of the right to resist is the support and recognition, both internal and external. The realization of such right might have active or passive form, expressed in direct or indirect actions. An important implementation condition of the right to resist is recognition and support at the national and international levels, and the support from its own people may have different forms, both open and explicit, which are difficult to set.

The right to resist cannot be deduced from international law, although some ground can be found, including international humanitarian law and the doctrine of responsibility to protect. The main source of the right to resist and rebellion is the concept of human rights, especially of universality and the natural character of rights.

The right of resistance is closely related to some other rights, in particular to selfdefense, right to arms, right to freedom of opinion and expression, right to freedom of peaceful assembly and association. But it is not completely identical to any of these rights.

Resistance may include non-violent and violent actions. These actions can be described by the concept of peaceful protest and civil disobedience, and, in exceptional cases, the rebellion. The activities that started as a peaceful, non-violent resistance may change to rebellion, especially if the level of abuse by public authorities only increases in response to protests and becomes unbearable.

Such an extreme form of the right to resist, as the right to rebel, is carried out in case if the non-violent means of resistance are exhausted or proven ineffective. The conditions (and bases) of the right of rebellion are phenomena, such as the following: (1) massive human rights violations by public authorities (quantitative criterion); (2) systematic human rights violations by public authorities (accumulating criterion), or (3) extraordinary human rights violations by public authorities (criterion by serious, explicit and violent nature of the violation). Ambiguous is an issue of the limits of the right of rebellion, its permissibility and proportionality, as well as whether it is possible to develop a mechanism for exercising this right.

In general, the problem of resistance and rebellion requires special attention, given the increase in their relevance. It is also advisable to confirm the right to resistance at the constitutional laws of the states as additional limits for the public authorities and a reminder that human rights are above all.

\section{References}

Alexy, R. Teorie der Grundrechte. 2nd edition. Frankfurt am Main: Suhrkamp, 1994, p. 548.
Babin, B. Pravo na soprotivlenie kak globalnoe pravo. [Babin, B. The Right of Resistance as a Global Right]. NB: Voprosy prava i politiki. 2013, (5): 
181-200 [interactive]. [accessed on 2014-05-02]. <http://e-notabene.ru/ lr/article_817.html $>$.

Charter of Fundamental Rights and Freedoms. 1992 [interactive]. [accessed on 2014-08-20]. <http://www.usoud. cz/en/charter-of-fundamental- rightsand-freedoms/>.

Charter of the United Nations, June 26, 1945, 59 Stat. 1031, T.S. 993, 3 Bevans 1153, entered into force Oct. 24, 1945.

Constitution of Greece. 2008 [interactive]. [accessed on 2014-08-22]. <http://www. hellenicparliament.gr/en/Vouli-ton-Ellinon/To-Politevma/Syntagma/>.

Constitution of the Portuguese Republic. 1976 [interactive]. [accessed on 201408-21]. <http://app.parlamento.pt/ site_antigo/ingles/cons_leg/Constitution_VII_revisao_definitive.pdf $>$.

Constitution of the Republic of Benin. 1990 [interactive]. [accessed on 201408-21]. <http://www1.umn.edu/humanrts/research/benin-constitution. html>.

Constitution of the Republic of Estonia. 1992 [interactive]. [accessed on 201408-21]. <http://www.president.ee/en/ republic-of-estonia/the-constitution/ $>$.

Constitution of the Republic of Lithuania. Official Gazette. 1992, No. 33-1014.

Constitution of the Slovak Republic. 1992 [interactive]. [accessed on 2014-0819]. <http://www.constitution.org/ cons/slovakia.txt>.

Konstytucija Ukraini. [Constitution of Ukraine]. Vidimosti Verkhovnoi Radi (VVR), 2014, No. 30-141.

Conway, J. Civil Resistance and the Diversity of Tactics in the AntiGlobalization Movement: Problems of Violence, Silence, and Solidarity in Activist Politics. Osgoode Hall Law Journal. 2003, 41(2/3): 505-530.

Declaration on South Africa (12 Dec. 1979), A/RES/34/93O. UNGA 114.

Declaration on Principles of International Law Concerning Friendly Relations and Co-operation among States in accordance with the Charter of the United Nations, G.A. res. 2625, Annex, 25 UN GAOR, Supp. (No. 28), U.N. Doc. A/5217 at 121 (1970).

Declaration on the Granting of Independence to Colonial Countries and Peoples, G.A. res. 1514 (XV), 15 U.N. GAOR Supp. (No. 16) at 66, U.N. Doc. A/4684 (1961).

Dugard, J.; Reynolds, J. Apartheid, International Law, and the Occupied Palestinian Territory. The European Journal of International Law. 2013, 24(3): 867-913.

Dzhemiljev, M. Dzhemiljev $v$ OON: til'ky krimski tatari majut pravo na samovyznachennja Krimu. [Jemilev, M. Jemilev in UN: Only Crimean Tatars Have the Right to Self-Determination Crimea]. 2014 [interactive]. [accessed on 2014-08-20]. <http://www.5.ua/ukrajina/politika/ item/377520-dzhemiliev-v-oon-tilkykrymski-tatary-maiut-pravo-nasamovyznachennia-krymu >.

Ferzan, K. Self-Defense and the State. Ohio State Journal of Criminal Law. 2008, (5): 449-478.

Ginsburg, T.; Lansberg-Rodriguez, D.; Versteeg, M. When to Overthrow Your Government: The Right to Resist in the World's Constitutions. UCLA Law Review. 2013, 60(5): 1184-1260.

Glanville, L. The Responsibility to Protect Beyond Borders. Human Rights Law Review. 2012 [interactive]. [accessed on 2014-08-21]. <http://hrlr.oxford journals.org/content/12/1/1.full >. 
Hilal, S., et al. The Lawless Line. London Review of International Law. 2013, 1(1): 201-209.

Honoré, T. The Right to Rebel. Oxford Journal of Legal Studies. 1988, 8(1): 34-54.

Guzar, L. Pravo na povstannja - to je zakon prirodi. [Husar, L. The Right to Rebel - That Is Natural Law]. 2014 [interactive]. [accessed on 2014-01-19]. $<$ http://www.umoloda.kiev.ua/number/2395/180/85201>.

International Covenant on Civil and Political Rights (of 16 December 1966, entered into force 23 March 1976) G.A. res. 2200A (XXI), U.N. Doc. A/6316 (1966), 999 UNTS. 171.

Israeli Practices Affecting the Human Rights of the Palestinian People in the Occupied Palestinian Territory, including East Jerusalem. GA Res. (adopted on 18 December 2012) A/ RES/67/121.

Kaufmann, A. Small Scale Right to Resist. New England Law Review. 1985-1986, (21): 571-576.

Koller, P. Die Struktur von Rechten. In: Georg Meggle (Hg.). Analyomen 2. Proceedings des 2. Kongressses für Analytische Philosophie. Bd. 3. Berlin/ New York, 1997, p. 251-262.

Kozjubra, M. Vstupyvshy do skladu Rosijs'koi' Federacii', Krym ne zmozhe u majbutn'omu skorystatysja pravom na samovyznachennja. [Koziubra, M. Entering the Russian Federation, the Crimea Will not Be Able in the Future to Exercise the Right to Self-Determination]. 2014 [interactive]. [accessed on 2014-05-21]. <http://uacrisis.org/ ua/mikola-kozyubra/>.

Kolodij, A. Pro Krimsku agresiju Putina $i$ pravo nacij na samovyznachennja.
[Kolody, A. The Crimean Aggression of Putin and the Right of Nations to SelfDetermination]. 2014 [interactive]. 2014 [interactive]. [accessed on 201408-20]. <gopher://political-studies. $\mathrm{com} / ? \mathrm{p}=1071>$.

Kopel, D. The Scottish and English Religious Roots of the American Right to Arms: Buchanan, Rutherford, Locke, Sidney, and the Duty to Overthrow Tyranny. Bridges. 2005, 12(3/4): 291-312.

Kopel, D.; Eisen, J.; Gallant, P. The Human Right of Self-Defense. BYU Journal of Public Law. 2008, (22) [interactive]. [accessed on 2014-03-26]. <http:// ssrn.com/abstract $=1022097>$.

Kijvec, O. U poshukakh mizhnarodnogo prava: pereosmisljujuchy dzherela. [Kiivec, O. In Search the International Law: Reinterpreting the Sources]. Kam'janec-Podilckij: Oijum, 2011, p. 480 .

Lang, B. Civil Disobedience and Nonviolence: A Distinction with a Difference. Ethic. 1970, 80(2): 156-159. Legal Consequences of the Construction of a Wall in the Occupied Palestinian Territory (Request for Advisory Opinion) [2004] ICJ 28.

Lippman, M. Towards a Recognition of the Necessity Defense for Political Protesters. Wash. \& Lee L. Rev. 1991, (48): 235-251.

Miller, D. Retail Rebellion and the Second Amendment. Indiana Law Journal. 2011, (86): 939-977.

Miller, R. Self-Determination in International Law and the Demise of Democracy? Columbia Journal of Transnational Law. 2003, (41): 601-648.

Moland, J. The Value-Oriented Civil Rights Movement and Passive Resistance: An 
Expression of Civility in the Pursuit of Social Justice. Sociological Inquiry. 2002, 72(3): 442-455.

Pro samousunennja Prezidenta Ukraini vid vykonannja konstytucijnyh povnovazhen ta priznachennja pozachergovikh viboriv Prezidenta Ukraini. [On Withdrawal of the President of Ukraine to Perform the Constitutional Powers and Calling Early Presidential Elections in Ukraine]. Vidomosti Verhovnoi Radi (VVR), 2014, No. 11-158.

Orlik, P. Vivid prav Ukraini. [Orlik, P. Conclusion Rights of Ukraine]. 1712 [interactive]. [accessed on 2014-0825]. <http://cdiak.archives.gov.ua/v_ do_300_Konstytutsii_Orlyka.php >.

Paust, J. International Law, Dignity, Democracy, and the Arab Spring. Cornell International Law Journal. 2013, (1): 1-19.

Pettit, P. Legitimacy and Justice in Republican Perspective. Current Legal Problems. 2012, (65): 59-82.

Pogrebnjak, S.; Uvarova E. Soprotivlenie ugneteniju. Vosstanie. Revoljucija (teoretiko-pravovoj analyz $v$ svete doktriny prav cheloveka). [Pogrebnyak, S. P.; Uvarova, O. O. Resistance to Oppression. Rebellion. Revolution (Theoretical and Legal Analysis in the Light of the Human Rights Discourse)]. Pravo i gromadjanske suspilstvo. 2013, (2): 4-61.

Political Constitution of Peru. 1993 [interactive]. [accessed on 2014-08-22]. <http://www.congreso.gob.pe/_ingles/ CONSTITUTION_29_08_08.pdf $>$.

Rubin, E. Judicial Review and the Right to Resist. The Georgetown Law Journal. 2008, (97): 61-118.

Rimarenko, S. Prava nacii ta prava ljudini: mizh Sciloju $i$ Kharibdoju. Kiiv: Svitlograd, 2005, p. 78.
Ruys, T. Of Arms, Funding and "Nonlethal Assistance" - Issues Surrounding Third-State Intervention in the Syrian Civil War. Chinese Journal of International Law. 2014, 13(1): 13-53.

Sirij M. Krim. Pravo na samoviznachennja ne realizujetsja dvichi. [Siryi, M. Crimea. The Right to Self-Determination is not Implemented]. 2014 [interactive]. [accessed on 2014-03-16]. <http:// www.radiosvoboda.org/content/ article/25295825.html>.

Situation of Human Rights in the Syrian Arab Republic. GA Res. (adopted on 20 December 2012) A/RES/67/183.

Talmon, S. Recognition of Opposition Groups as the Legitimate Representative of a People. Chinese Journal of International Law. 2013, (2): 219-253.

United Nations Millennium Declaration (adopted 8 September 2000) GA A/ $\mathrm{RES} / 55 / 2$.

Universal Declaration of Human Rights, G.A. res. 217A (III), U.N. Doc A/810 at 71 (1948).

Wall, I. The Defence of Conscience: A Limited Right to Resist. Hibernian Law Journal. 2004, 4(1): 275-288.

Walter, E. From Civil Disobedience to Obedient Consumerism - Influences of Market-Based Activism and EcoCertification on Forest Governance. Osgoode Hall Law Journal. 2003, 41(2/3): 531-565.

Zilbershats, Y. Apartheid, International Law, and the Occupied Palestinian Territory: A Reply to John Dugard and John Reynolds. The European Journal of International Law. 2013, 24(3): 915-928. 


\title{
TEISĖ PRIEŠINTIS IR TEISĖ SUKILTI
}

\author{
Yulia Razmetaeva \\ Yaroslavo Mudryi nacionalinis teisès universitetas, Ukraina
}

Anotacija. Straipsnyje analizuojamos teisè priešintis ir teisè sukilti (maištauti), apžvelgiant ịvairiu mokslininkų nuomones apie šių teisių samprata ir esmę bei pateikiant autoriaus nuomonę šiuo klausimu. Taip pat identifikuojamos šiu teisių realizavimo salygos, tikslai ir formos.

Teise priešintis gali būti suprantama kaip veiskmai be prievartos ir tiesioginiai prievartos veiksmai, o teisé sukilti laikoma ekstremalia pirmosios teisès išraiškos forma. Kiekvienos šiu teisiu realizavimui yra nustatytos specialios sąlygos (griežtesnès sukilimui), kaip teisètas tikslas, masiniai žmogaus teisių pažeidimai ir pan. Šiu teisiu pripažinimas ir palaikymas jas igyvendinant yra reikalaujamas iš žmonių ir gali būti reikalaujamas iš tarptautinès bendruomenès.

Reikšminiai žodžiai: teisè priešintis, teisè sukilti, valdžios institucijos, tarptautinè teise, žmogaus teisès.

\section{THE RIGHT TO RESIST AND THE RIGHT OF REBELLION}

\author{
Yulia Razmetaeva \\ Yaroslav Mudryi National Law University, Kharkiv, Ukraine
}

Summary. The right to resist and the right to rebel have again become relevant as legal problems. Their justifications traditionally derive from natural law, human rights, the principle of the lesser evil or of the social contract. Interpretation of the right to resist expresses the tendencies to the law of people, in particular, the right to self-determination, distinguishing national and international understanding, and underscores the special nature of such right. Also, two-level research of the right to resist should be distinguished research of the right to resist - the first is a debate about the nature character and legislative consolidation of this right, partly focused on preventive-limiting its properties, whereas the second one is updated at the time of social upheaval and legal concerns, and it contains not only the evaluation of the events, but sometimes attempts to justify ex post risk of abuse and original post-legitimation of public authorities.

An important condition for the existence of the right to resistance is a legitimate aim. This could be called the internal condition, which is provided by those who implement this right. Other condition (which can be called external) and the base of implementation should recognize certain actions, acts or decisions by public 
authorities - those that violate human rights are illegal and unfair. At the same time, the purpose and result of the right to resistance may be changes in the public authorities, the termination of abuse of authority and violation of human rights by its agents, return to democratic legal regime or change in the constitutional system, aimed at creating a state of law, as well as in some cases, when combined with the right to selfdetermination, - the achievement of independence.

The author of the present paper considers that the right to resist is an individual right, a human right. But the author inclines to the idea of the collective nature of the right to resist implementation, but warns against simply counting the number of persons engaged in it. In other words, it does not matter how many people commit acts, but it does matter how many people support them. Considering the modalities of implementing the right to resist, it should be noted that these forms can be active or passive, expressed in actions directly or indirectly.

The right of rebellion is an extreme form of the right to resist, which is carried out in case if the non-violent means of resistance are exhausted or proved ineffective. The conditions (and bases) of the right of rebellion are phenomena, such as the following: (1) massive human rights violations by public authorities (quantitative criterion); (2) systematic human rights violations by public authorities (accumulating criterion); or (3) extraordinary human rights violations by public authorities (criterion by serious, explicit and violent nature of the violation). Ambiguous is an issue of the limits of the right of rebellion, its permission and proportion, as well as whether it is possible to develop a mechanism for exercising this right.

Keywords: the right to resist, the right of rebellion, public authorities, international law, human rights.

Yulia Razmetaeva, Yaroslavo Mudryi nacionalinio teisès universiteto Valstybès ir teisès teorijos departamento asistentè, socialinių mokslų (teisè) daktarè. Mokslinių tyrimų kryptys: žmogaus teisès, pilietinè visuomenè, informacinių technologijų teisiniai klausimai.

Yulia Razmetaeva, PhD, Yaroslav Mudryi National Law University, Department of Theory of State and Law, Assistant. Research interests: human rights, civil society, legal issues of information technologies. 